\title{
MEMoIR: THE GROWTH OF A COMMUNity
}

UMA PARAMESWARAN

University of Winnipeg

uma_param@yahoo.com

Received: 27-05-2013

Accepted: 15-09-2013

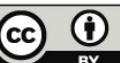

I didn't know it then, but when my husband and I arrived in Manitoba in September 1966, we were two of the pioneers of the Indo-Canadian community, that numbered about fifty. All immigrants from Asia who came about the same time we did, were likewise pioneers, for Manitoba in the early 1960s was predominantly white and Eurocentric. There was a Chinatown in Winnipeg, as in most other cities, but it was small and stereotyped as though running a laundry was the only occupation the Chinese had. Over the last fifty years, each of Manitoba's fifty plus ethnic communities has become three hundred times bigger and perhaps it is time to place on record some of the early steps in the growth of a community and the vast differences between then and now. Here, I will talk only about the community from India with a few anecdotes to spice up the reading.

This was before Canada got its own flag. We, the early immigrants, were pretty ignorant about our rights and responsibilities as landed immigrants, and Winnipeggers were even more ignorant about us. When someone came to our door to collect information for the electoral list, I said that perhaps I was not eligible to vote since I was born in India, and she heartily responded, "That is okay, dear, we all belong to the same mother country." At the time I was hesitant to tell her that India had got rid of the British flag twenty years earlier. Today, We have Indo-Canadian elected members of the Legislature and school boards and such, and non-Indian members of the various political parties regularly visit our places of worship at election time to show their support for the community. However, our numbers in public offices is not large. We still seem to be in more traditional jobs. We could certainly do with more workers in the field of journalism, police force etc.

A majority of the fifty individuals were associated with the university, as students or faculty. There were a few school teachers and doctors, but no businessmen, not even anyone 
running a spice-and-convenience store. Since the grocery stores - they were not called supermarkets - sold the spices so essential to Indian cooking in mini-size bottles that would have scarcely sufficed for a week's meals, we quickly found out how to get one-pound spice jars sent by bus from a store in Vancouver, consignments that had to be picked up from the Bus Depot downtown. The first spice store opened in the early 1970s and one day I overheard the storekeeper advising a white customer who had come in because she had heard there were spices that could keep away ants from her vegetable beds. He sold her a bag of crushed red chilies saying that would surely keep away all unwanted creatures if sprinkled around the base of her beds or plants. My neighbour, an excellent gardener, still buys a jar of red-chili powder every spring for the same purpose.

At that time, Bangladesh was not yet born, and the handful of people from Pakistan and the fifty or so people from India saw themselves as from the same ethnic group. The community, though small, started developing various cultural wings as early as mid 1960s. The India Association was one of the earliest to sprout and we participated in the newly-started Folklorama, an annual festival of multiculturalism where various ethnic communities showcased their cultural heritage of music and dance at various centres across the city.

Today 15,000 of Winnipeg's population of 700,000 trace their origins to south Asia. Not only are there separate organizations of Indians, Pakistanis, Bangladeshis and SriLankans, but various organizations formed by smaller linguistic groups such as the Punjabi, Gujarati, Malayali, Bengali, Tamil, Karnataka etc. The India Association has now lost its cohesive power to bring the community under one umbrella and its only significant work is towards the oneweek annual event of organizing the India Pavilion at Folklorama. Perhaps this disintegration of a central body is peculiar to the Indian community and not seen in other ethnic communities. Perhaps it is due to the many major languages of India, and the fact that language, next to religion, seems to be the adhesive base of all groupings.

Whereas the university was at one time the place of work for the majority, today the professions range across the board, with entrepreneurial businesses having the largest population. Indeed, the Indo-Canadian Business Directory of 2012 lists 150 businesses owned or largely run by Indo-Canadians, ranging from Snow Removal to Real Estate, Auto-Repair to Wedding Planners. There are a dozen spice stores and a dozen restaurants, and as many beauty-salons, and clinics for alternate health-care. 
In the 1960s, there were no places of worship for Sikhs, Muslims and Hindus. Today, there are eight gurudwaras, six mosques, four Hindu temples, and at least one Buddhist meeting place, and of course we have a great many Christians going to different churches. However, unlike the Koreans and Chinese, we do not seem to have any church that has a large membership from the community. Communal worship seems to be growing across all religious affiliations. Religion could become a divisive factor, but we are not there yet. Places of worship have been targeted by perpetrators of hate crime but such instances are few as of now.

In those early days, we of the Hindu community, celebrated various festivals in groups at our homes, while the main annual celebration of the festival of Deepavali was held at some community centre or church basement with a potluck dinner and songs and dances. Then, in the early 1970s, the Hindu Society of Manitoba was formed. Community members who were knowledgeable in the rituals got a license to officiate at weddings, and the temple was the site for the few weddings that took place.

Today, there is one or other special worship held at the main Hindu Temple every day. Customs and rituals that average Hindus have given up in India are practised conscientiously at these events, and the attendance is sizeable. As for wedding celebrations, they have been moved out to large banquet halls of five-star hotels, with special licenses to have the sacred fire lit in the banquet hall (the fire-crew on red-alert) and with the guest list going well beyond five hundred invitees on an average. This phenomenon really needs some sociological study. What makes immigrants take on practices that they might not have followed in India? What makes the bride and groom, one of whom is often not a Hindu, agree to these traditional rituals and lavish display of ostentation? Do they do it to satisfy their parents? Do the parents act out of some outmoded sense of "it has to be done this way?" Do the young people really feel any emotional attachment to the religious rituals? Or is it the Bollywood extravaganza of the affair that appeals to them. This is for sociologists to study.

In those days, immigration to Manitoba from India consisted of very well-educated people, fluent in English. But because we looked different, others assumed we did not know English. I had a friend from India who was single. She got friendly with another new immigrant (who was from Europe) who spoke no English at all, and they decided to go to Folklorama pavilions together. Whenever they were addressed by anyone, like the driver of the bus they took for instance, the other person assumed the white woman knew English and addressed her 
rather than my friend. Also, it was always interesting to watch the expression on the listener's face during my walks when I told any neighbour I taught English at the university.

Today, a great many Indo-Canadians, women mainly, speak no English at all, and never will. I have a friend who sells home-made Indian snacks and I regularly go to her place to pick up purchases, and we have long conversations with her speaking in Gujarati and me in Hindi. I don't understand much of what she says and she too probably understands little of what I say! There are numerous government-subsidized agencies that teach English to immigrants who don't know either of Canada's official languages but where is the need to learn English - one can get by very comfortably because even in supermarkets, one only needs to see the picture on the packages to buy what one needs to.

In those early days, everyone knew everyone else in the community, and we met in large groups for dinner almost every weekend at people's apartments, for most of us lived in apartments. The few of us who already had children would lay them to sleep on the host's bed or on the carpet in the second bedroom, and cluster in the living room, twenty of us squeezed on sofas, chairs, ottomans. We were all in one room, and so the talk moved from men's topics cars and India's politics - to women's interests - the best place to buy kitchen tools, groceries, or on recipes (since we came from different regions of India, this was always good to share). Today, most of us, even new immigrants, live in houses, and given the larger space, gender separation occurs without one being aware of it - the women converge in one room or part of a room, the men in the other, while the children play in the basement, and only the babies still sleep on the hosts' or guest bed. This gender segregation is worth a study. As communities grow and prosper, and people don't need to be crowded in a single room, are we entrenching old ways of social interaction?

There are two other interesting points about the partying aspect of Indo-Canadian life. One is a new phenomenon I just heard about - house-builders are advertising the concept of a two-kitchen custom built home, one kitchen for the party-crowd built in the modern open-floor plan within the living room area, and the other for the actual cooking, behind scenes! This is an innovative idea, for Indian cooking is rather elaborate and aromatic (or odoriferous if you will). The other aspect of the partying life is more problematic. In the wake of Canada's Family Reunification immigration policy, a great many parents were sponsored into the country starting in the 1980s. The place within the family that is accorded to the seniors merits an in-depth study. 
While some still rule the family as in India, others find themselves dependent on their adult son and daughter-in-law, and sometimes end up as unpaid baby sitters, cooks and cleaners, relegated to their basement suite while the family party on the main floor. Perhaps we are looking at a small number of cases, but it would be very relevant in the sociological context as to the quality of life experienced by sponsored seniors, especially widowed mothers.

Sad to say, there is no literature on any of the above aspects, neither literary nor sociological. As I have said in one of my early essays, "Ganga in the Assiniboine", immigrants do not turn to developing their creative talents till they have gone through the settlement process in terms of their own job, children settling down within the school system etc. and so it is natural that no one turned to writing in the first twenty years of community history. But there have been no writers in English in the city other than myself. No one in the community reads my works. Thanks to a literary minded staff writer of a community newspaper published six times a year, most of my books are reviewed when they first appear, but hardly a handful have bought any of my books, if sales records of the local major bookstore is any indication. There are one or two who write in Punjabi but they have not fared any better as far as the community's reading habits go. Tyrrell Mendes was one of the early poets but he has turned to photography and drives through Manitoba photographing old churches! Winnipeg's public libraries now stock quite a few Punjabi, Hindi and Gujarati books, reflecting the demand for them. But these are mostly books by writers living in India, not by writers living here.

So, Manitoba is a desert as far as Indo-Canadian literature is concerned. But it is the same story with most of the other provinces, an average of one writer per province except for the provinces of British Columbia and Ontario. Gurdev Chauhan is making an effort with his South Asian Ensemble, published out of Ontario, and Sadhu Binning is still active in British Columbia. However, in every province there are numerous community newspapers, published mainly for advertising local businesses and social events.

In the history of Indo-Canadian writing in English, an impetus was given when Moyez Vassanji and his wife Nurjehan Aziz started The Toronto South Asian Review in 1981. It provided a forum for the South Asian diaspora as also for the Caribbean diaspora. In 1993, it was renamed Toronto Review of Contemporary Writing Abroad and the revised mandate opened it to other writers as well, but the journal was discontinued a few years later. Today TSAR, as it is called, is a publisher of books only. 
In conclusion, the Indo-Canadian community in Manitoba has come a long way from its beginnings in the 1960s and is flourishing in many ways, but it is now too big to be held under a single social umbrella. Instead we have several active sub-communities knit by language or religion.

To record the beginnings, I started a blog <indocanadiansinmanitoba.blogspot.com $>$ but I am afraid I have not concentrated on the project and it is still floating in cyberspace, waiting for me.

\section{WORKS CITED}

Parameswaran, UMA (1985). "Ganga in the Assiniboine: Prospects for Indo-Canadian Literature" in M.G.Vassanji (ed). A Meeting of Streams: South Asian Canadian Literature. Toronto: TSAR Books. Reprinted in Parameswaran, Uma (2007). Writing the Diaspora: Essays on Culture and Identity. Jaipur: Rawat Publications. 